\title{
IMPLEMENTASI PERSATUAN DAN KESATUAN DALAM KEHIDUPAN BERBANGSA DAN BERNEGARA
}

\author{
Abdul Rohim \\ IIK STRADA INDONESIA
}

$\underline{\text { Abdul300881@gmail .com }}$

\begin{abstract}
Abstrak
Sila ke-tiga Pancasila yang berbunyi Persatuan Indonesia mempunyai nilai mengutamakan persatuan atau kerukunan bagi seluruh rakyat Indonesia. Pengamalan butir Pancasila ke-tiga tidak lepas dari kondisi Indonesia yang mana diberkahi keragaman suku, budaya, bahasa dan juga agama. Persatuan Indonesia mengutamakan kepentingan dan keselamatan negara dari pada kepentingan pribadi atau golongan. Negara mengakui dan menyatakan bangsa Indonesia adalah satu kesatuan . Negara melalui pemerintah harus benar-benar menjaga dan memperkuat bangsa Indonesia dengan persatuan. Disisi lain, makna setiap sila dalam Pancasila sebagai dasar negara harus dipahami setiap warga Indonesia , temasuk sila ketiga yang berbunyi persatuan Indonesia. Tanpa memahami maknanya Pancasila mungkin hanya dianggap sebagai slogan semata . Makna setiap sila pancasila harus menjadi landasan, fondasi utama,dan titik acuan Bangsa Indonesia dalam mengatur kehidupan berbangsa dan bernegara .
\end{abstract}

Kata kunci : Pancasila, Persatuan Indonesia

\section{Latar Belakang}

Bangsa Indonesia yang majemuk terdiri dari berbagai macam suku, agama, ras, adat, dan golongan. Semua keberagaman tersebut bisa di katakan sebagai sebuah kekayaan yang dimiliki oleh Negara Kesatuan Republik Indonesia (NKRI). Oleh karena itu tidak sedikit warga mancanegara yang ingin datang ke Indonesia hanya untuk melihat keberagamannya. Namun keberagaman yang dimiliki Indonesia rentan untuk terjadinya konflik yang terjadi di tengahtengah masyarakat. Konflik yang terjadi akan membuat sesama bangsa Indonesia saling membenci satu sama lain. Bahkan, suatu konflik yang terjadi secara terus menerus bisa saja menyebabkan terjadinya perpecahan sesame bangsa Indonesia. Maka dari itu, Negara Indonesia membuat atau membentuk dasar negara supaya semua supaya tidak ada konflik dan perpecahan 
yang terjadi diantara bangsa Indonesia. Dasar negara itu di kenal dengan Pancasila. Adanya Pancasila ini untuk menciptakan kehidupan yang rukun, damai, dan tentram di masyarakat. Pancasila sendiri memiliki lambing dan makna yang terkandung didalamnya. Selain itu, setiap sila-sila memiliki nilai-nilai yang dapat diimplentasikan dalam kehidupan sehari-hari. Begitupun pada sila kke tiga yang kaitannya sangat erat dengan meyatukan keberagaman yang ada di Indonesia.

\section{Kasus Masalah}

Jakarta_Ketua PP Muhammadiyah Anwar Abbas meyatakan, isu separatis di Papua harus di tangani serius oleh pemerintah. Menurutnya, saat ini apa yang terjadi di Bumi Cendrawasih mengancam kesatuan bangsa. Situasi di Papua saat ini benar-benar harus mendapat perhatian serius dari kita bersama karena apa yang terjadi di sana sekarang ini benar-benar telah mengancam persatuan dan kesatuan kita sebagai bangsa. Mereka telah menyatakan ingin keluar dari Negara Kesatuan Republik Indonesia dan membentuk negara sendiri yaitu negara Papua.. Tegas Anwar Abbas pada keterangan tulis pada Senin (30/11/2020)

\section{Tinjauan Pustaka}

\section{A. Pengertian Persatuan dan Kesatuan}

\section{Persatuan}

Persatuan berasal dari kata satu yang berarti uituh dan tidak terpecah-belah. Arti lebih luasnya, yaitu berekumpulnya ber macam-macam corak dari berbagai kalangan, ras, budaya, dan adat istiadatdalam masyarakat yang bersatu dan serasi.

\section{Kesatuan}

Kesatuan merupakan hasil dari persatuan yang telah menjadi utuh. Hal ini dilakukan untuk terhindar dari disintegrasi, maka sangat dibutuhkan persatuan di Indonesia.

\section{> Perbedaan persatuan dan Kesatuan}

Walau istilah persatuan dan kesatuan saling bersinggungan, keduanya memiliki suatu perbedaan. Persatuan merupakan suatu proses dalam keadaan membentuk masyarakat untuk bersatu, sementara kesatuan merupakan wujud bersatunya masyarakat yang sudah terbentuk. 


\section{Makna Persatuan dan Kesatuan}

Terdapat tiga makna penting yang terkandung dalam persatuan dan kesatuan bagi bangsa Indonesia. Adapun arti dari ketiga makna persatuan dan kesatuan yang harus di ketahui , antara lain:

1. Selalu menjalin rasa kepercayaan, kebersamaan, dan saling melengkapi antar bangsa demi menjaga rasa persatuan dan kesatuan bangsa.

2. Selalu berupaya untuk dapat saling menghargai satu sama lain antar sesame bangsa yang berlandaskan rasa kemanusiaan sehingga dapat tercapai kehidupan yang serasi dan harmonis.

3. Selalu menjalin rasa kekeluargaan, persahabatan, saling tolong menolong, serta nasionalisme antarbangsa yang dapat menjaga persatuan dan kesatuan bangsa.

\section{B. Nilai-Nilai yang Terkandung dalam Sila Persatuan Indonesia}

Persatuan dan kesatuan bangsa Indonesia masih menjadi suatu hal yang sangat penting. Persatuan Indonesia bahkan di tuliskan pada sila ke tiga Pancasila. Sila ketiga yang berbunyi Persatuan Indonesia menjelaskan dalam masyarakat Indonesia yang majemuk mengandung nilai persatuan bangsa dan kesatuan wilayah sebagai pengikat yang menjadi keutuhan nasional atas dasar Bhineka Tunggal Ika. Di kutip dari buku dari buku Super Complete Kelas 4, 5, 6 SD/MI oleh Meity Mudikawaty, $\operatorname{dkk(2018:~657),~nilai~tersebut~menempatkan~}$ kepentingan bangsa dan negara di atas kepentingan pribadi atau golongan tertentu yang diserasikan dalam rangka kepentingan bangsa dan negara. Apabila persatuan dan kesatuan tidak ada lagi di Indonesia, perpecahan pasti akan terjadi diantara masyarakat Indonesia. Oleh karena itu, kita harus tetap bersatu sebagaimana para pendahulu kita yang sudah bersatu melawan melawan para penjajah

\section{Manfaat-Persatuan dan Kesatuan}

Di dalam persatuan dan kesatuan mengandung nilai-nilai positif. Adapun nilai yang ada dalam persatuan dan kesatuan, antara lain :

1. Persatuan dan kesatuan dapat mengatasi semua perbedaan dengan penuh kesabaran dan kesadaran. 
2. Persatuan dan kesatuan antar warga negara dapat membuat pembangunan nasional berjalan lancar, aman, baik dan sesuai harapan.

3. Bangsa Indonesia akan lebih mudah maju dan berkembang dengan menerima perbedaan yang muncul.

4. Akan lebih mudah untuk mencapai tujuan nasional yang tertuang dalam pembukaan UUD 1945 alenia keempat.

5. Dengan adanya persatuan dan kesatuan, akan tercipta suasana aman, damai, dan tenteram dalam negara. Terutama karena adanya sikap toleransi, solidaritas, dan setia kawan di antara warganya.

6. Persatuan dan kesatuan dapat mewujudkan kehidupan yang seimbang, harmonis, serta serasi antar manusia.

7. Pelaksanaan gotong royong di lingkungan sekitar akan berjalan lancar tanpa adanya kendala.

8. Saling menjaga kerukunan dan menjalin silaturahmi antar bangsa.

9. Menjaga keutuhan Negara Kesatuan Republik Indonesia (NKRI) supaya tidak mudah terpecah belah oleh orang lain.

10. Akan lebih ,mudah mengatasi berbagai gangguan baik yang muncul dari dalam maupun dari luar.

\section{Pembahasan}

\section{A. Persatuan dan Kesatuan}

Indonesia merupakan negara yang mempunyai banyak keberagaman dan perbedaan, sehingga perlu adanya persatuan dan kesatuan. Dengan adanya keberagaman tersebut, tentu penting memiliki sikap persatuan dan kesatuan antarsesama masyarakat demi menjaga keutuhan bangsa dan negara Indonesia. Tanpa adanya persatuan dan kesatuan, bangsa Indonesia akan mudah terpecah belah.. Persatuan dan kesatuan adalah senjata paling ampuh bagi bangsa Indonesia untuk mewujudkan masyarakat yang sejahtera,adil, dan makmur. Hal ini sesuai dengan semboyan Bangsa Indonesia yaitu "Bhineka Tunggal Ika" yang berarti "Berbeda-beda tetapi tetap satu jua". Semangat persatuan dan kesatuan dapat menghasilkan jiwa gotong royong yang dapat menyelesaikan permasalahan secara bersama., 


\section{B. Implementasi Persatuan dan Kesatuan di Lingkungan Masyarakat}

Menjalani kehidupan dengan tenang, damai, dan nyaman merupakan manfaat persatuan dan kesatuan. Ada banyak sikap maupun tindakan yang dapat kita lakukan dalam menerapkan persatuan dan kesatuan.

* Penerapan Nilai Persatua dan Kesatuan di Lingkungan Keluarga

a. Bekerja sama membersihkan lingkungan rumah

b. Menghormati antar anggota keluarga

c. Menolong adik mengerjakan PR

d. Berbakti kepada orang tua.

e. Gotong royong menjaga kebersihan dan keamanan lingkungan.

\section{* Penerapan Nilai Persatua dan Kesatuan di Lingkungan Sekolah}

a. Mengerjakan tugas-tugas bersama teman-teman tanpa membedakan suku, budaya maupun agama. Dampak positifnya warga belajar akan saling bertukar pikiran, saling membantu memberikan pemahaman, sehingga memperoleh pengetahuan, dan tugas dapat diselesaikan dengan baik.

b. Saling menghargai dan menghormati. Dampak dari sikap saling menghargai dan menghormati adalah terciptanya suasana belajar yang tertib, teratur, dan menyenangkan.

c. Menghargai pendapat teman. Perbedaan pendapat selalu ada dalam kehidupan bersama. Sikap menghargai pendapat orang lain atau teman, akan berdampak positif yaitu terwujudnya suasana yang rukun, damai, tidak ada perselisihan.

d. Gotong royong membersihkan tempat belajar bersama. Menjaga kebersihan tempat belajar yang dilakukan secara gotong royong akan menghasilkan ruangan yang bersih, rapi dan nyaman untuk belajar.

e. Semangat mengikuti kegiatan pembelajaran. Warga belajar yang saling memberikan semangat dalam mengikuti pembelajaran, akan berdampak positif yaitu kesuksesan dalam belajar.

- Penerapan Nilai Persatua dan Kesatuan di Lingkungan Masyarakat

a. Saling menghormati dan menghargai antar warga masyarakat

b. Memiliki rasa persatuan meski berbeda agama, suku dan budaya

c. Melestarikan budaya dari daerah lain 
d. Memiliki rasa toleransi antar warga

e. Menghargai dan mendukung pemimpin negara yang terpilih secara demokratis sesuai aturan yang berlaku.

\section{Kesimpulan}

Bangsa Indonesia merupakan bangsa yang majemuk terdiri dari berbagai suku, agama, ras, adat dan golongan. Itu semua merupakan anugrah dari Yang Maha Kuasa, yang patut kita syukuri dan harus di jaga bersama, agar kemajemukan itu tidak menimbulkan konflik. Maka dari itu semenjak Bangsa Indonesia merdeka kita berlandaskan UUD 1945 dan Pancasila, sebagai perangkat untuk menjaga persatuan dan kesatuan bangsa Indonesia, agar tercipta persatuan dan kesatuan bangsa, serta tercapainya masyarakat yang aman, damai dan tentram.

\section{Daftar Pustaka}

Persatuan dan Kesatuan Bangsa

https://www.liputan6.com/tag/persatuan-dan-kesatuan-bangsa

Makna Persatuan dan Kesatuan

https://www.suara.com/news/2021/05/23/075543/makna-persatuan-dan-kesatuan?page=all

Manfaat Persatuan dan Kesatuan

https://www.bola.com/ragam/read/4501280/pengertian-persatuan-dan-kesatuan-makna-manfaatserta-contohnya-yang-perlu-dipahami

Penerapan Nilai Persatuan dan Kesatuan

https://www.bola.com/ragam/read/4680780/contoh-contoh-penerapan-nilai-persatuan-dan-

kesatuan-dalam-kehidupan-ketahui-manfaatnya 